http://nv.nltu.edu.ua

https://doi.org/10.15421/40280414

Article received $19.03 .2018 \mathrm{p}$.

Article accepted $26.04 .2018 \mathrm{p}$.

$@$ Correspondence author

O. F. Kovalyshyn

kovalyshynlesya@ukr.net

удк 63.332 .2

О. Ф. Ковалишин, Н. І. Кришеник

Львівський національний аграрний університет, м. Дубляни, Украӥна

\title{
УДОСКОНАЛЕННЯ МЕТОДИЧНИХ ПІДХОДІВ ДО ФОРМУВАННЯ ПРАВОВИХ ОБМЕЖЕНЬ ПІД ЧАС ВИКОРИСТАННЯ ЗЕМЕЛЬНИХ ДІЛЯНОК У СИСТЕМІ ДЕРЖАВНОГО ЗЕМЕЛЬНОГО КАДАСТРУ
}

\begin{abstract}
Вирішення проблем сталого розвитку регіонів, екологічної безпеки довкілля, визначення правових відносин щодо землі та іншого нерухомого майна потребують всебічного кадастрового забезпечення. В Україні створюється нова земельно-кадастрова система на основі узаконених прав, яка представлятиме собою єдину державну геоінформаційну систему відомостей про землі, розташовані в межах державного кордону. На цей час вона не містить повних правових, просторових, якісних характеристик про земельні ділянки, як природного ресурсу землі, що не дає змоги встановити всіх обмежень, обтяжень прав під час їх використання. Обгрунтовано потреба удосконалення методичних підходів до формування відомостей у системі Державного земельного кадастру. Через брак повної інформації про землю, відбувається накладання прав одних суб'єктів на права інших в межах однієї земельної ділянки. Перехід до світової практики в частині формування земельної ділянки дасть змогу визначити іï як індивідуалізовану частину "землі" зі встановленими межами та сформованими правами щодо органічно поєднаних на ній ресурсів. 3 огляду на це необхідно шляхом розроблення проектів землеустрою щодо організації і встановлення меж територій природно-заповідного фонду та іншого природоохоронного призначення, оздоровчого, рекреаційного, історико-культурного, лісогосподарського призначення, земель водного фонду та водоохоронних зон, обмежень у використанні земель та їх режимотвірних об'єктів сформувати відомості інших кадастрів у системі Державного земельного кадастру. Запропонований підхід через визначення, накладання і відображення відомостей про природні ресурси у вигляді окремих шарів на Публічній кадастровій карті дасть змогу сформувати повноту відомостей щодо обмежень у використанні земельних ділянок, удосконалити правові відносин, узгодити інтереси приватних і суспільних потреб, що сприятиме створенню інформативної та багатофункціональної системи Державного земельного кадастру. Нагромадження різноманітних даних у межах однієї системи значно поліпшить адміністрування цих даних та підвищить ефективність територіального використання земельної ділянки.
\end{abstract}

Ключові слова: кадастри; відомості; права; землеустрій; проект; територіальні зони.

Вступ. Система земельного кадастру та нерухомості $\epsilon$ важливою суспільною інституцією у країнах з ринковою економікою. Вирішення проблем сталого розвитку регіонів, екологічної безпеки довкілля, визначення правових відносин щодо землі та іншого нерухомого майна потребують всебічного кадастрового забезпечення. Сьогодні кадастрові дані $є$ допоміжними у визнанні прав власності чи користування на земельні ділянки та на основі узаконених прав на них формується сучасна система Державного земельного кадастру (Bavrovska \& Palamarchuk, 2010; Kustovska \& Mamon, 2013).

Земля, як природний ресурс, є важливим елементом біосфери, просторовим базисом, об'єктом з покладами корисних копалин, водних ресурсів, що потребує просторового визначення місця розташування та правового визнання цих об'єктів. Через брак повної інформації про землю, відбувається накладання прав одних суб'єктів на права інших в межах однієї земельної ді- лянки, які не будуть відображені ні у системі Державного земельного кадастру, ні у реєстрі речових прав на нерухоме майно (Zemelnyi kodeks, 2001; Kodeks Ukrainy, 1994).

Оскільки у нашій країні створюється нова система Державного земельного кадастру на основі узаконених прав, то важливо методично правильно підійти до формування відомостей у ній. Від іï інформаційного наповнення залежить успішний розвиток земельних відносин та ефективне використання земельних ресурсів (Zakon Ukrainy, 2011; Zakon Ukrainy, 2013).

Аналіз останніх досліджень та публікацій. Про потреба удосконалення системи відомостей та методів ї отримання у Держаному земельному кадастрі наголошує низка дослідників. Зокрема, А. Третяк (2014) зазначає, що в Україні сьогодні великою проблемою стає процес запису інформації про земельні та інші природні ресурси і власність на них, використання та оцінку зе-

\section{Інформація про авторів:}

Ковалишин Олександра Федорівна, канд. екон. наук, доцент. Email: Kovalyshynlesya@ukr.net

Кришеник Надія Іванівна, канд. екон. наук, доцент. Email: nadya_kryshenyk@ukr.net

Цитування за ДСтУ: Ковалишин О. Ф., Кришеник Н. І. Удосконалення методичних підходів до формування правових обмежень під час використання земельних ділянок у системі державного земельного кадастру. Науковий вісник НлтУ України. Серія Економічна. 2018, т. 28, № 4. С. 78-82

Citation APA: Kovalyshyn, O. F., \& Kryshenyk, N. I. (2018). Improvement of Methodic Approaches to Formation of Legal Restrictions While Using Land Parcels in the System of the State Land Cadastre. Scientific Bulletin of UNFU, 28(4), 78-82.

https://doi.org/10.15421/40280414 
мель у складі державного земельного кадастру (Panas \& Malanchuk, 2014; Postanova KMU, 2012).

Бавровська Н., Паламарук Л. (2010) вважають, що важливою передумовою запровадження в Україні сучасного земельного кадастру $\epsilon$ розробка та прийняття законодавчого та нормативно методичного забезпечення, яке базувалося б на єдиній концепції і повною мірою відповідало сучасним вимогам до кадастрово реєстраційної діяльності та враховувало позитивний світовий досвід (Zakon Ukrainy, 2003; Tretiak, 2014).

Кустовська О., Мамон М. (2013) зазначають, що у сучасному світі на зміну моноцільовим кадастрам приходять поліфункціональні багатоцільові кадастри, які $є$ за суттю цілісними інформаційними системами. Серед сучасних світових стандартів побудови кадастровореєстраційних систем особливого визнання набули Кадастр 2014, ISO 19100, EULIS, Open GIS, INSPIRED.

У зазначених працях наголошено на потреба формування багатофункціональної системи кадастру, яка відповідала б європейським стандартам (Zakon Ukrainy, 2013; Savlisian, n.d.).

Метою дослідження $є$ обгрунтування необхідності вдосконалення методологічних засад формування відомостей Державного земельного кадастру в частині визначення та встановлення правових обмежень під час використання земельних ділянок.

Матеріали та методи дослідження. Нормативноправове ведення Державного земельного кадастру регламентується Земельним кодексом, Законом України "Про Державний земельний кадастр" (2011), "Порядком ведення Державного земельного кадастру" (2012). Об'єктом виступає земельна ділянка, яка згідно зі Земельним кодексом є частиною земної поверхні з установленими межами, певним місцем розташування, 3 визначеними щодо неї правами. Формування іiї відбувається за результатами складення документації із землеустрою після погодження у встановленому порядку та до прийняття рішення про затвердження органом державної влади або органом місцевого самоврядування. Право власності на земельну ділянку розповсюджується на простір, що знаходиться над та під поверхнею ділянки на висоту і на глибину, необхідну для зведення житлових, виробничих та інших будівель i споруд. Поряд з тим, згідно зі ст. 23 Кодексу про надра (1994), землевласники та землекористувачі мають право видобувати за певних умов для своїх господарсько-побутових потреб корисні копалини.

У світовій практиці земельна ділянка, як основна складова частина нерухомості, визначає все, що знаходиться під нею із проекцією до центру землі і все, що знаходиться над нею, продовжене в нескінченність, включаючи постійні об'єкти, приєднані до неї природою або людиною, а також права на ці об'єкти. Відмінності у визначеннях подано на рис 1.

Зазначене зображення несе різне інформаційне навантаження на кадастрові системи у нашій країні та за кордоном. Так, в інших державах, для прикладу, наявність корисних копалин, запасів води, характеристик довкілля та ін., відображаються в кадастрі, що обмежує використання наземної частини поверхні землі, або ж дає можливість одержання компенсації в умовах, несприятливих для проживання. Саме тому існує чітка тенденція до подальшого розвитку багатофункціонального кадастру, побудованого на різноманітній інформації про земельні ресурси. Цим самим, створюються нові можливості для підвищення захисту прав власників та користувачів земельних ділянок, збагачення кадастру новими відомостями та показниками, що дає змогу вирішувати ширше коло завдань щодо використання землі як просторового базису та цільового призначення.

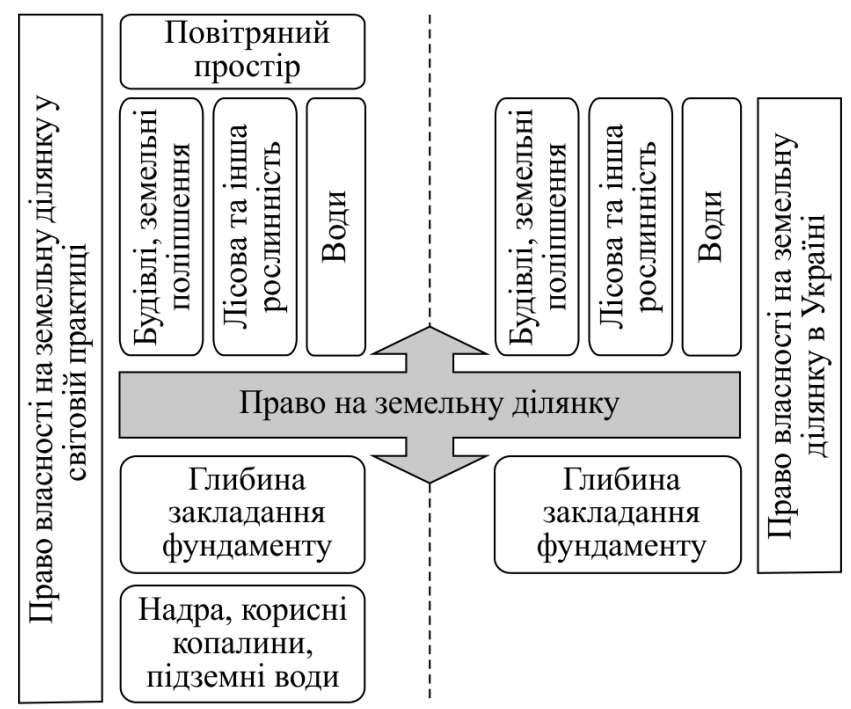

Рис. 1. Графічне зображення просторового визначення права на земельну ділянку

В Україні Державний земельний кадастр - єдина державна геоінформаційна система відомостей про землі, розташовані в межах державного кордону, на цей час не містить повних правових, просторових, якісних характеристик про земельні ділянки, як природного ресурсу землі, що не дає змоги встановити всіх обмежень, обтяжень прав за їх використання. Поряд 3 тим, прийнято низку нормативно-правових актів, які регулюють питання ведення кадастрів, обліку та формування відомостей про природні ресурси у відповідних державних службах та відомствах. Аналізуючи дослідження Р. М. Панас, М. С. Маланчук та Г. Ф. Савлісян, зведемо у таблицю інформацію про підстави формування відомостей у нинішніх системах кадастрів.

Отже, кожен із кадастрів формує свою облікову систему ресурсів без реєстрації речових прав на них. Вони зосереджені у різних державних службах та відомствах, містять інформацію, яка забезпечує діяльність тієї чи іншої галузі.

Для прикладу, Державний облік вод складається 3 Державного обліку водокористування, поверхневих вод і підземних вод. Водними об'єктами є поверхневі, підземні, внутрішні морські води та територіальне море. Різні служби проводять їх облік: Державна служба України з надзвичайних ситуацій облікує за розділом "Поверхневі води", Держводагентство України - "Водокористування", Державна служба геології та надр України - "Підземні води". Держгеонадра за результатами робіт iз складання Державного водного кадастру за розділом "Підземні води" передає відомості (зміни до відомостей) про обмеження у використанні земель до Державного земельного кадастру відповідно до Порядку інформаційної взаємодії між кадастрами та інформаційними системами, затвердженого постановою Кабінету Міністрів України від 3 червня 2013 р., № 483. Попри зазначене у Державному земельному кадастрі, через низку причин зазначена інформація відсутня. 
Таблиця. Нормативно-правове та методичне забезпечення ведення кадастрів

Нормативно-правовий документ 1 Вид документу

Лісовий кодекс та Постанова Кабінету Міністрів від 20 чер-
вня 2007 р., № 848 "Про затвердження Порядку ведення дер-
жавного лісового кадастру та обліку лісів", Наказ Державно-
го комітету лісового господарства України від 01 жовтня
2010 р., № 298 "Про затвердження Інструкції про порядок ве--
дення державного лісового кадастру і первинного обліку лі-
сів".

Водний кодекс України від 06 червня 1995 р., № 213/95-ВР, Постанова Кабінету Міністрів України від 8 квітня 1996 р., № 413 "Про затвердження Порядку ведення державного водного кадастру".

Кодекс України про надра від 27.07.1994 р., № 132/94-ВР,

Постанова Кабінету Міністрів України від 31 січня 1995 р., № 75 "Про затвердження Порядку державного обліку родовищ, запасів і проявів корисних копалин".

Закону України від 05.10.2000 р., № 2026-III "Про курорти", Постанови Кабінету Міністрів України від 23.05.2001 р., №562 "Про затвердження Порядку створення і ведення Державного кадастру природних територій курортів".

Закон України від 05 жовтня 2000 р., №2026-III "Про курорти", Постанови Кабінету Міністрів України від 26 липня 2001 р., № 872 "Про затвердження Порядку створення і ведення Державного кадастру природних лікувальних ресурсів".

Закон України від 16 червня 1992 р., № 2456-XII "Про природно-заповідний фонд", Наказ Міністерства охорони навколишнього природного середовища від 16 лютого 2005 р., № 67 "Про затвердження Інструкції про зміст та складання документації державного кадастру територій та об'єктів природно-заповідного фонду України".

Ведення кадастру регулюється Законом України від 13 грудня 2001 р., № 2894-III "Про тваринний світ", Постановою Кабінету Міністрів від 15 листопада 1994 р., № 772 "Про порядок ведення державного кадастру тваринного світу"

Закон України 09 квітня 1999 р., № 591-XIV "Про рослинний світ", Постанова Кабінету Міністрів України від 22 лютого 2006 р., № 195 "Про затвердження Порядку ведення державного обліку і кадастру рослинного світу"

Постановою Кабінету Міністрів України від 21 квітня 2006 р., № 554 "Про затвердження Порядку функціонування національної системи оцінки антропогенних викидів та абсорбції парникових газів, які не регулюються Монреальським протоколом про речовини, що руйнують озоновий шар"

Сьогодні відомості Державного земельного кадастру формуються на правовій основі після реєстрації земельних ділянок у реєстрі речових прав на нерухоме майно і зареєструвати обмеження у їх використанні неможливо через відсутність інформації у ньому та не візуалізації на Публічній кадастровій карті. Тому немає правової основи визначити та встановити обмеження на земельні ділянки через відсутність інформації із інших кадастрів.

Ці відомості інших кадастрів необхідно відобразити в Державному земельному кадастрі шляхом розроблення проектів землеустрою щодо організації і встановлення меж територій природно-заповідного фонду та іншого природоохоронного призначення, оздоровчого, рекреаційного, історико-культурного, лісогосподарського призначення, земель водного фонду та водоохоронних зон, обмежень у використанні земель та їх режимотвірних об'єктів, які будуть служити основою для накладання обмежень у користуванні земельною ділянкою. Ці проекти є підставою для обліку їх у системі Державного земельного кадастру та відображення за допомогою
Документація кадастру ведеться на основі даних державного земельноо кадастру, матеріалів лісовпорядкування, інвентаризації, обстежень та первинного обліку лісів окремо за власниками лісів і постійними лісокористувачами:

облік якісного і кількісного стану лісового фонду України; 2) поділ ісів на категорії залежно від основних виконуваних ними функцій; 3) рошова оцінка лісів (у необхідних випадках); 4) інші показники.

Систематизований звіт відомостей про: поверхневі, підземні, внутрішні морські води та територіальне море; обсяги, режим, якість і використання вод (водних об'єктів); водокористувачів (окрім вторинних); водогосподарські об'єкти, що забезпечують використання води, очищення та скид зворотних вод (споруди для акумуляції та регулювання поверхневих і підземних вод; споруди для забору та транспортування води; споруди для скиду зворотних вод; споруди, на яких здійснюється очищення зворотних вод (з оцінкою їх ефективності).

Звіти про результати геологознімальних, пошукових, геологорозвідувальних, тематичних, проектно-пошукових та науково-дослідних робіт геологічного профілю, річних звітів гірничодобувних підприємств, звітів про результати технологічних випробувань мінеральної сировини, техніко-економічних обгрунтувань, інших документів, що стосуються оцінки та списання запасів.

Відомості кадастру формуються з різних документованих джерел, зокрема, Державного земельного кадастру і топографо-геодезичного фонду у текстовій, цифровій та графічній (картографічній) формах. Створюється автоматизована система ведення кадастру, яка базується на використанні ГІС-технологій.

Формуються відомості у формі текстових, цифрових та графічних (картографічних) матеріалів щодо видів (типів) природних лікувальних ресурсів: мінеральні і термальні води, лікувальні грязі та озокерит, ропа лиманів та озер, морська вода, природні об'єкти і комплекси із сприятливими для лікування, медичної реабілітації та профілактики захворювань кліматичними умовами.

Документація передбачає відомості про правовий статус, належність, режим, географічне положення, кількісні та якісні характеристики цих територій та об'єктів, їх природоохоронну, наукову, освітню, виховну, рекреаційну й іншу цінність заповідного фонду.

Систематизовано сукупність відомостей про географічне розповсюдження видів (груп видів) тварин, їх чисельність і стан, характеристики середовища їх існування і сучасного господарського використання та інші необхідні дані. Організація ведення державного кадастру тваринного світу, координація діяльності, пов'язаної з виконанням кадастрових робіт, а також державний контроль за якістю і вірогідністю даних, що включаються до кадастру

Ведеться облік кількісних, якісних та інших характеристик природних рослинних ресурсів, обсягу, характеру та режиму їх використання, а також для здійснення систематичног
ними змінами в рослинному світі.

Дані кадастру опубліковані на сайті Національного центру обліку викидів парникових газів.

електронних документів у вигляді територіальних зон пошарово на Публічній кадастровій карті. Пропонуємо логічно-смислову схему накопичення та відображення правових обмежень у системі кадастру (рис. 2).

Накопичення різноманітних даних в межах однієї системи значно поліпшить адміністрування цих даних та підвищить ефективність територіального використання земельної ділянки. Система обліку Державного земельного кадастру буде ефективною за умови зосередження у ній реальних відомостей про правову структуру власності, користування земельними ділянками та обмежень у їх використанні.

Прийняття запропонованих рішень покращить інформативність про наявність природних ресурсів, що забезпечить надійність і точність визнання власності, правових обмежень на територію земельної ділянки та створить передумови для вирішення проблем ії сталого розвитку, загалом економіки регіонів, екологічної безпеки довкілля, визначення правових відносин щодо землі та іншого нерухомого майна. Отже, відбувати- 
меться забезпечення рівності права власності на землю громадян, юридичних осіб, територіальних громад та держави, сформується модель обов'язкової поведінки суб'єктів земельних правовідносин. Це передбачатиме дію чи бездіяльність власника, користувача земельної ділянки щодо її використання відповідно до закону, договору чи рішення суду для узгодження приватних i суспільних потреб та інтересів під час використання землі.

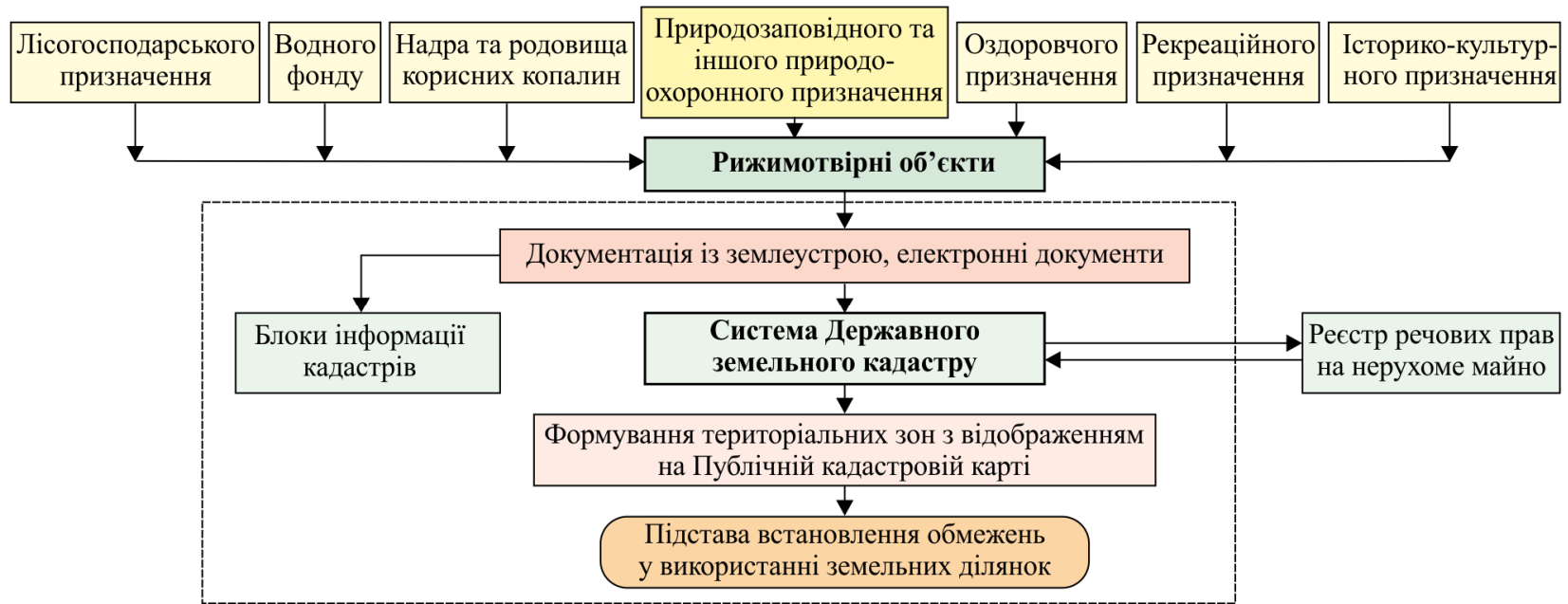

Рис. 2. Логічно-смислова схема формування правових обмежень режимотвірних об'єктів у системі Державного земельного кадастру

Висновок. У системі Державного земельного кадастру, де об'єктом є земельна ділянка, в сучасних умовах потребує удосконалення визначення її поняття. Перехід до світової практики в частині формування земельної ділянки дасть змогу визначити їі як індивідуалізовану частину "землі" з встановленими межами та сформованими правами щодо органічно поєднаних на ній ресурсів. Запропонований підхід через визначення, накладання та відображення відомостей про природні ресурси у вигляді окремих шарів дасть змогу забезпечити інформативність та багатофункціональність системи кадастру, удосконалити правові відносини в обмеженні використання та охорони земель.

\section{Перелік використаних джерел}

Bavrovska, N. M., \& Palamarchuk, L. V. (2010). Svitovyi dosvid formuvannia kadastru nerukhomosti ta yoho vplyv na formuvannia kadastrovykh system Ukrainy. Ekonomika APK, 20, 20-24. Retrieved from: http://www.agrosvit.info/pdf/20_2010/7.pdf. [In Ukrainian].

Kustovska, O. V., \& Mamon, M. O. (2013). Kadastrovi systemy yak efektyvnyi mekhanizm derzhavnoho upravlinnia. Ekonomika ta innovatsiinyi rozvytok natsionalnoho hospodarstva, 3(4-1), 65-67. Retrieved from: http://nbuv.gov.ua/UJRN/inek_2013_3_15.pdf. [In Ukrainian].

Kodeks Ukrainy. (1994). Kodeks Ukrainy pro nadra vid 27 lypnia 1994 roku №132/94-VR. Retrieved from: http://zakon3.rada.gov.ua/laws/show/132/94-\%D0\%B2\%D1\%80. [In Ukrainian].
Panas, R. M., \& Malanchuk, M. S. (2014). Kadastr pryrodnykh resursiv. Lviv: Vydavnytstvo Lvivskoi politekhniky. 436 r. [In Ukrainian].

Zakon Ukrainy. (2011). Pro Derzhavnyi zemelnyi kadastr: Zakon Ukrainy vid 07.07.2011 r., №3613-// Holos Ukrainy vid 06.08.2011 №145. Retrieved from: http://zakon2.rada.gov.ua/laws/show/361317. [In Ukrainian].

Postanova KMU. (2012). Pro zatverdzhennia Poriadku vedennia Derzhavnoho zemelnoho kadastru: Postanova Kabinetu Ministriv Ukrainy vid 17 zhovtnia 2012 r., № 1051. Retrieved from: http://zakon2.rada.gov.ua/laws/show/1051-2012-п. [In Ukrainian].

Zakon Ukrainy. (2013). Pro zatverdzhennia Poriadku informatsiinoi vzaiemodii mizh kadastramy ta informatsiinymy systemamy: Zakon Ukrainy vid 3 chervnia 2013 r., № 483. Retrieved from: http://zakon3.rada.gov.ua/laws/show/483-2013-\%D0 \%BF. [In Ukrainian].

Zakon Ukrainy. (2003). Pro zemleustrii: Zakon Ukrainy vid 22 travnia 2003 r., № 858-IV. Retrieved from: http://zakon2.rada.gov.ua/laws/show/858-15. [In Ukrainian].

Savlisian, H. F. (n.d.) Ohliad kadastriv, yaki funktsionuiut v Ukraini. Retrieved from: https://3222.ua/article/oglyad_kadastrv_yak_funktsonuyut_v_ukran.htm. [In Ukrainian].

Tretiak, A. M. (2014) Kontseptualni zasady rozvytku modeli zemelnoho kadastru v Ukraini. Zemlevporiadnyi visnyk, 4, 22-26. [In Ukrainian].

Zemelnyi kodeks. (2001). Zemelnyi kodeks Ukrainy vid 25.10.2001 r., № 2768-III. Retrieved from: http://zakon2.rada.gov.ua/laws/show/2768-14. [In Ukrainian].

А. Ф. Ковалишин, Н. И. Крышеник Львовский национальный аграрный университет, г. Дубляны, Украина

\section{УСОВЕРШЕНСТВОВАНИЕ МЕТОДИЧЕСКИХ ПОДХОДОВ К ФОРМИРОВАНИЮ ПРАВОВЫХ ОГРАНИЧЕНИЙ ПРИ ИСПОЛЬЗОВАНИИ ЗЕМЕЛЬНЫХ УЧАСТКОВ В СИСТЕМЕ ГОСУДАРСТВЕННОГО ЗЕМЕЛЬНОГО КАДАСТРА}

Решение проблем устойчивого развития регионов, экологической безопасности окружающей среды, определение правовых отношений относительно земли и другого недвижимого имущества требуют всестороннего кадастрового обеспечения. В Украине формируется новая земельно-кадастровая система на основе узаконенных прав, которая будет представлять собой единую государственную геоинформационную систему сведений о землях, расположенных в пределах государственной границы. В настоящее время она не содержит полных правовых, пространственных, качественных характеристик о земельных участках, как природного ресурса земли, не позволяет установить всех ограничений, обременений прав при их использовании. Обоснована необходимость совершенствования методических подходов к формированию сведений в системе Государственного земельного кадастра. Из-за отсутствия полной информации о земле, происходит наложение прав одних субъектов на права других в пределах одного земельного участка. Переход к мировой практике в части формирования земельного участка позволит определить ее как индивидуализированную часть "земли" с установленными границами и сфор- 
мированными правами по органично сочетающихся на ней ресурсам. В связи с этим необходимо путем разработки проектов землеустройства по организации и установлению границ территорий природно-заповедного фонда и другого природоохранного назначения, оздоровительного, рекреационного, историко-культурного, лесохозяйственного назначения, земель водного фонда и водоохранных зон, ограничений в использовании земель и их режимообразуюцих объектов сформировать сведения других кадастров в системе Государственного земельного кадастра. Предложенный подход через определение, наложение и отображение сведений о природных ресурсах в виде отдельных слоев на Публичной кадастровой карте позволит сформировать полноту сведений об ограничениях в использовании земельных участков, усовершенствовать правовые отношения, согласовать интересы частных и общественных потребностей, будет способствовать созданию информативной и многофункциональной системы Государственного земельного кадастра.

Ключевые слова: земельный участок; Государственный земельный кадастр; право собственности; ограниченное пользование; кадастры; учет земель; территориальные зоны.

\author{
O. F. Kovalyshyn, N. I. Kryshenyk \\ Lviv National Agrarian University, Dublyany, Ukraine
}

\title{
IMPROVEMENT OF METHODIC APPROACHES TO FORMATION OF LEGAL RESTRICTIONS WHILE USING LAND PARCELS IN THE SYSTEM OF THE STATE LAND CADASTRE
}

Solution of the problems of sustainable development of regions, ecological safety of the environment, determination of legal relations concerning land and other real estate objects requires appropriate cadastre supply. In Ukraine, one observes the process of establishment of a new land-cadastral system on the base of approved rights. It will be a common state geo-informational system of information about the lands, located within the state borders. Nowadays, the system does not include complete information about legal, spatial, qualitative characteristics of land parcels as natural resources of land. Thus, it prevents determining of all restrictions, encumbrances of the rights while using them. The article argues the necessity to improve the methodic approaches to formation of the data in the system of the State Land Cadastre. Lack of complete information about land predetermines overlapping of the rights of some subjects on the rights of the others within the same land parcel. Transition to the world practice in the field of land parcels formation will help to define it as a separate part of "land" with determined boundaries and established rights concerning organically combined resources on the land parcel. Thus, it is necessary to supply the information of other cadastres in the system of the State Land Cadastre by means of development of the projects of land surveying concerning organization and determination of boundaries of the territories of natural-reserve fund and other environmental intention, curative, recreational, historic-cultural, forest-farming intention, lands of water fund and water-protective areas, restrictions in land use and their regime-forming objects. The proposed approach will supply complete information concerning restrictions of land parcel use, will improve legal relations and coordinate interests of private and social needs by determination and depiction of the data about natural resources in the form of separate layers on a Public Cadastre Map. It will supply formation of an informative and multifunctional system of the State Land Cadastre. Accumulation of various data within the unified system will substantially improve administrating of the data and rise efficiency of territorial use of a land parcel.

Keywords: cadastres; information; rights; land surveying; project; territorial zones. 